\title{
Online tudatosság a Z-generációban
}

\author{
Zvada Anna \\ Bláthy Ottó Villamosipari Szakgimnázium, Miskolc
}

\section{Bevezető gondolatok}

Tanulmányaim során mind többször hívták fel figyelmünket az oktatóink, hogy a hagyományos oktatási kereteket elhagyva fel kell fedeznünk az e-learning és e-learning 2 oktatási formák által kínált lehetőségeket. Én is elkezdtem kutatni ebben az irányban, és találkoztam az e-learning 2-vel, amely azt mondja, hogy nem egyszerüen az oktatás színterét kell átvinni az internetre, hanem ki kellene használni a közösség adta tudást. Mint valami hangyaboly, mindenki hozzáadhatja a tudását a nagy egészhez, és a diákok ebben a halmazban létezve sajátítanák el a számukra szükséges ismereteket, mint ahogy a premodern társadalmakban a gyermek a szüleitől, a közösségtől tanulta meg mindazt, amit ők átadni tudtak, és amit a gyermek meg tudott tanulni. Azonban felmerül az első probléma: a gyermek hogyan tud válogatni abból a mérhetetlen információhalmazból, ami a rendelkezésére áll. A második probléma az, hogy honnan tudja, hogy minden információ helytálló, amit betettek a közös nagy tudásba, hiszen azt ténylegesen senki sem szüri, részeit esetleg, de az egészet nem. Azonban azt is fel kellett fedeznem, hogy ez nem egy lehetőség, amelyet vagy választunk, vagy nem, hanem egy folyamat, ami már megtörtént, már a web 2.0 világában élünk, a tartalmakat már a közösség szerkeszti, már nincs olyan weboldal, amelynek ne lenne dinamikus tartalma, és ne rendelkezne chat- vagy fórumrésszel. Manapság a szülők leginkább remélni tudják, hogy gyermekeik korukat meghazudtoló bölcsességgel képesek felismerni a kibertér által rejtett értékeket vagy csapdákat. Kutatásom központjában pedig az a kérdés áll, hogy a diákok tudatában vannak-e annak, hogy a világháló információtartalma nem feltétlenül helytálló, és ha igen, akkor pedig szürik-e valamilyen módon a tartalmakat. A felmérést online kérdőíves módszerrel végeztem el, a vizsgált területekre adott válaszok a kérdőív eredményei alapján történtek.

Feltárandó témakörök: (1) milyenek a diákok általános internetezési szokásai, (2) tanulnak-e az internet segítségével, (3) tisztában vannak-e azzal, hogy a média (és itt főként az internetes média) által nyújtott információhalmaz egy része helytelen elemeket tartalmazhat, (4) a kapott információkat szürik-e bármilyen módon, (5) amennyiben szürik, melyek a leggyakoribb mechanizmusok? 


\section{A kérdőíves vizsgálat eredményei}

Az alábbiakban néhány statisztikai adat alapján hívnám fel a figyelmet arra, hogy a kérdéskör, amelyben a kutatást végeztem és a középiskolai korosztályt foglalja magába, valójában hány diákot is érinthet évente. A 2015/2016. tanévben Magyarországon 1723 000-an vesznek részt oktatásban, amelyből 446000 fö tartozik a középiskolai korosztályba, és ebböl 179832 fö tanul szakközépiskolában 180843 fö pedig gimnáziumban. Az anonim kérdöíves kutatás területileg Borsod-Abaúj-Zemplén megyében történt, ahol a 2014-es adatok szerint 15151 fö tanult szakközépiskolában és 10940 fó pedig gimnáziumban. Az elöbbiek közül 100 fő vett részt a felmérésben (KSH, 2016).

Ahhoz, hogy megértsük a hipotézist, be kell látnunk, hogy a diákok internet-hozzáférése közelít a 100\%-hoz (pontosan 91,2\%) (kérdőívek alapján). Az olyan háztartásban, ahol gyermek is van, az IKT-eszközök(asztali számítógép) megléte 66,3\%-os (1. ábra) (KSH, 2006).

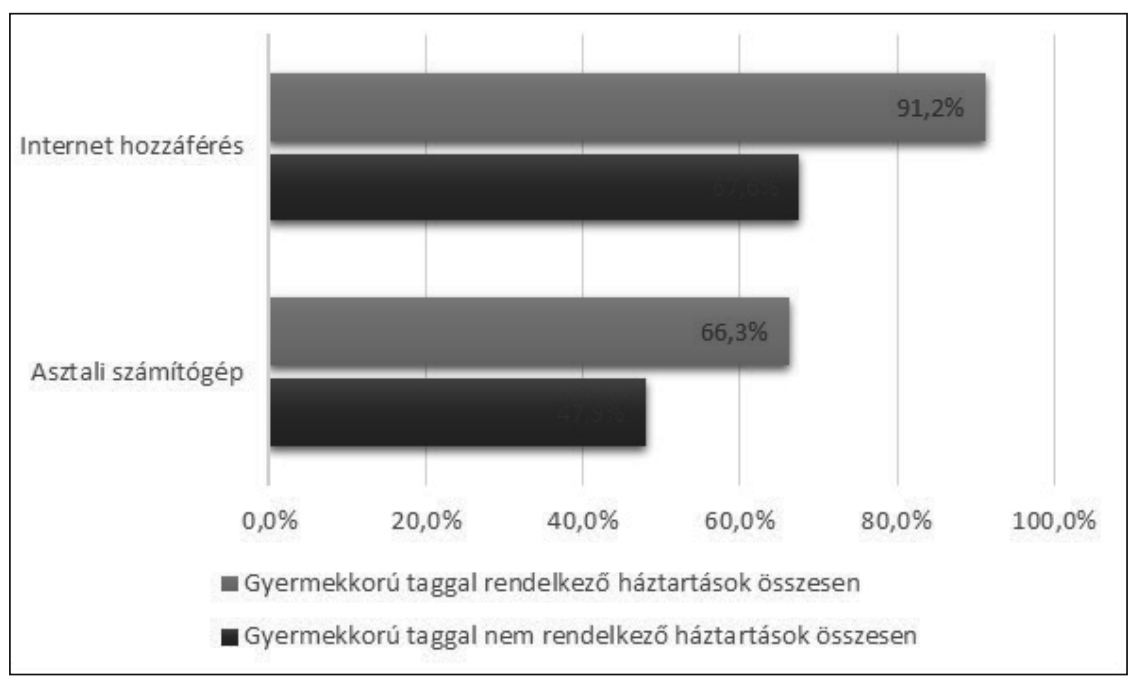

1. ábra

A háztartások IKT-ellátottsága az azonos típusú háztartások százalékában (Forrás: saját készités a KSH (2016) adatai alapján)

Érdekes, hogy azokban a háztartásokban, amelyekben van gyermek, mind az IKT-eszközök, mind az internetelérés megléte százalékosan sokkal magasabb, mint azokban a háztartásokban, ahol nincs. Ez is abba az irányba mutat, hogy a kutatásban érintett generáció tagjai mindinkább az internet adta lehetőségekkel élve nőnek fel, és nem csak felhasználják, igénylik is ezen elemek meglétét az életükben. A középiskolás korcsoport 94,2\%-a napi rendszerességgel használja, és mindössze $2,1 \%$ az, aki csak havi rendszerességgel internetezik (2. ábra) 
(KSH, 2016). Felmérésem szerint a diákok arra a kérdésre, hogy „van-e otthon internetelérésük", 97\%-a válaszolt igennel.

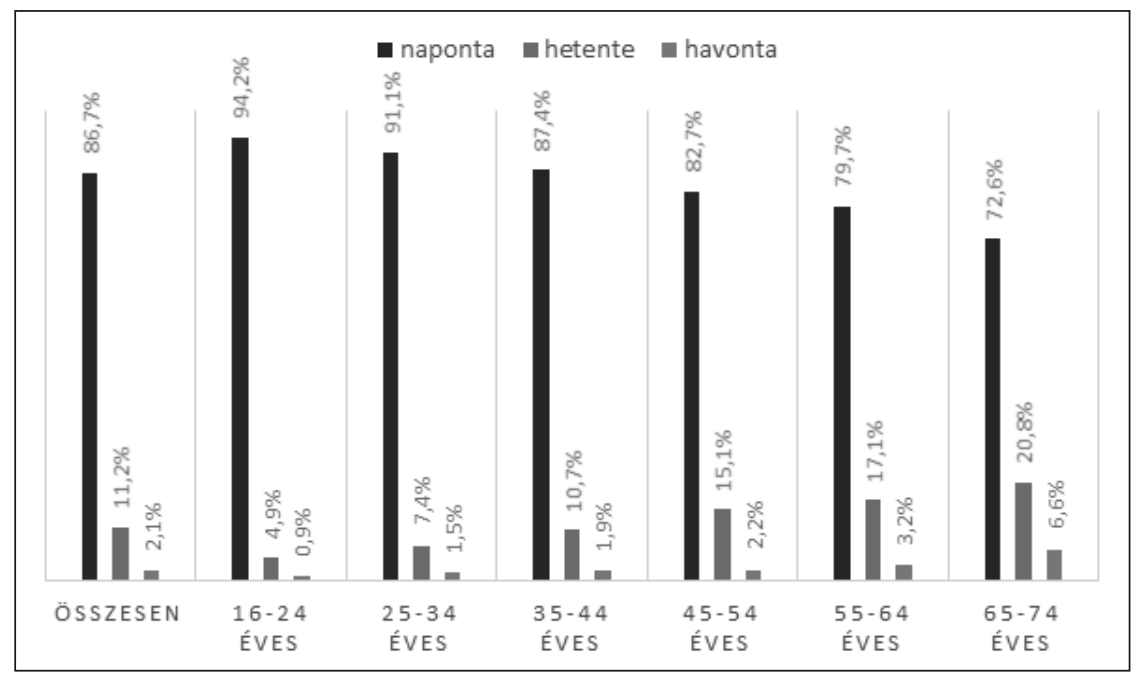

2. ábra

Az internethasználat gyakoriságának megoszlása életkor szerint (Forrás: saját készités a KSH adatai alapján)

Az iskolai számítógép-ellátottság, még ha lassan is, de emelkedik, átlagosan 4 gyerek jut egy számítógépre (KSH, 2014). A megkérdezettek 31\%-a nyilatkozta, hogy az iskolában számítógépről internetezik, és $18 \%$ adta azt a választ, hogy nem internetezik az iskolában.

Az internet használata egyre inkább begyürüzik az iskolai élet mindennapjaiba, erre mutat rá az a kérdés, miszerint az iskolai tanórákon használnak-e internetet a gyerekek. A válaszok 77\%-a igen volt, ez nem is meglepő, hiszen a mai diákoknak van informatikaórájuk, és a tananyag függvényében használhatják az internetet. A kérdőívek alapján kiderült, hogy nem csak az informatikaórán használják, hanem már az elméleti órákon is, ahol oktatófilmekkel, internetes kérdőívvel színesítik a tanárok az óráikat.

A 3. ábra korosztályra lebontva mutatja, hogy a diákok napi szinten mennyi időt töltenek az interneten. A legtöbb diák átlagosan 1-3 órát internetezik egy hétköznap, ami már önmagában is soknak számít, különösen, ha hozzávesszük, hogy átlagosan délután négy órára érhetnek haza. Elgondolkodtató az a kérdés, hogy vajon hol is élik a fiatalok az életüket. Még megdöbbentőbb, hogy a megélt éveik számával növekszik az internetezéssel töltött órák száma. Az elöbbiekben még „,csak” 1-3 óráról esett szó, de a megkérdezett 11. osztályosok 30\%a, valamint a 12 . osztályba járók $22 \%$-a is több mint 6 órát tölt a világhálón. 


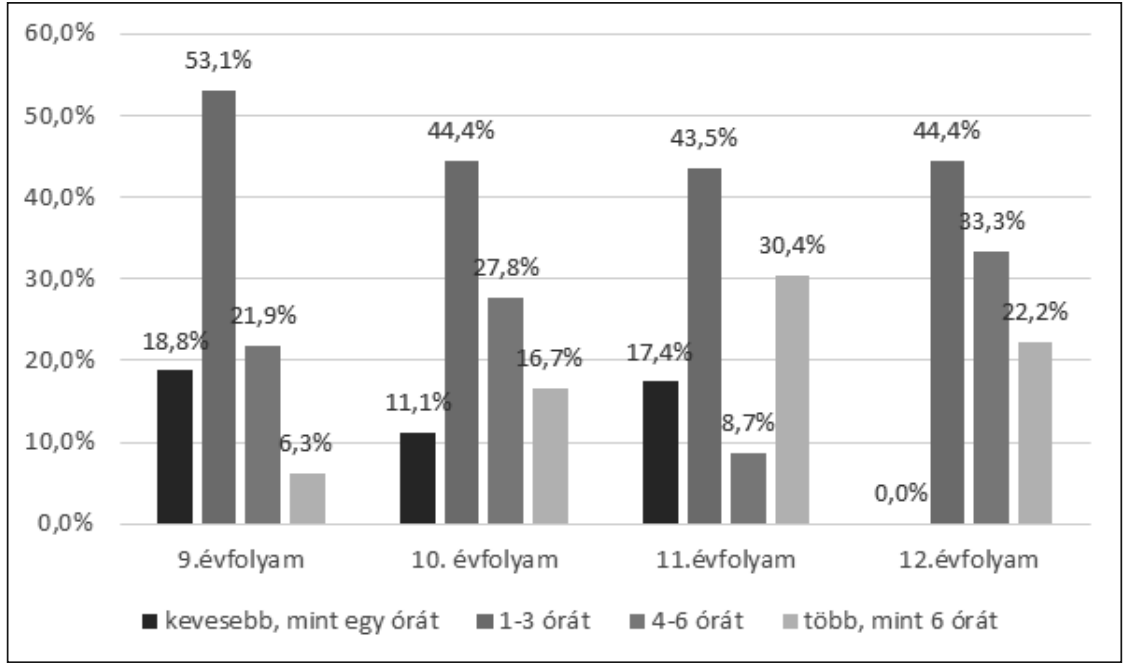

3. ábra

A diákok internetezési szokásai egy átlagos hétköznapot tekintve (Forrás: saját készités a kérdöiv eredményei alapján)

Ez a tendencia a hétvégékre is igaz marad (a 11. évfolyamosokat kivéve), a diákok több mint 50\%-a 3 óránál többet tölt az interneten, a 12. osztályosok esetében ez több mint 74\% (4. ábra).

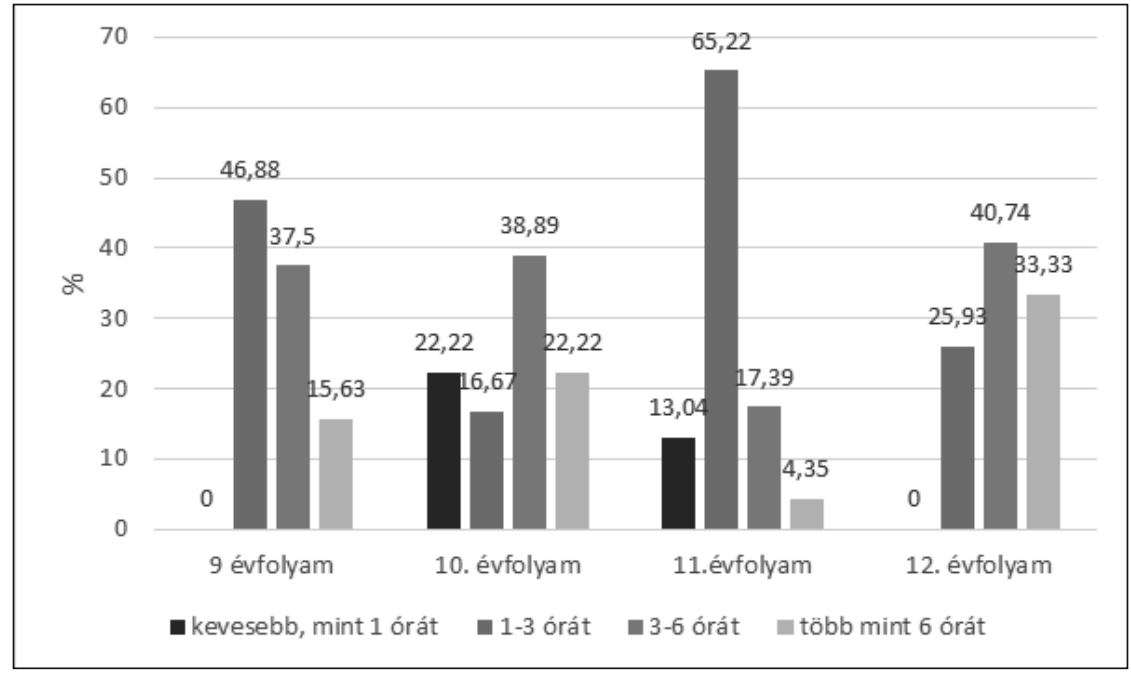

\section{4. ábra}

A diákok internetezési szokásai egy átlagos hétvégi napot tekintve (Forrás: saját készités a kérdöiv eredményei alapján) 
Felvetődött a kérdés, hogy ha ennyi időt töltenek ebben a közegben, mit is csinálnak, hiszen nemcsak hétvégenként, hanem a hétköznapok tetemes százalékában is ezzel foglalják el magukat. A válaszokból az derült ki, hogy leginkább zenehallgatásra, videók megtekintésére, játékra és kapcsolattartásra használják. A megkérdezettek mindössze 16\%-a mondta, hogy ha meg kellene neveznie azt az öt funkciót, amire leginkább használják az internetet, akkor a tananyag keresése, letöltése benne lenne (5. ábra).

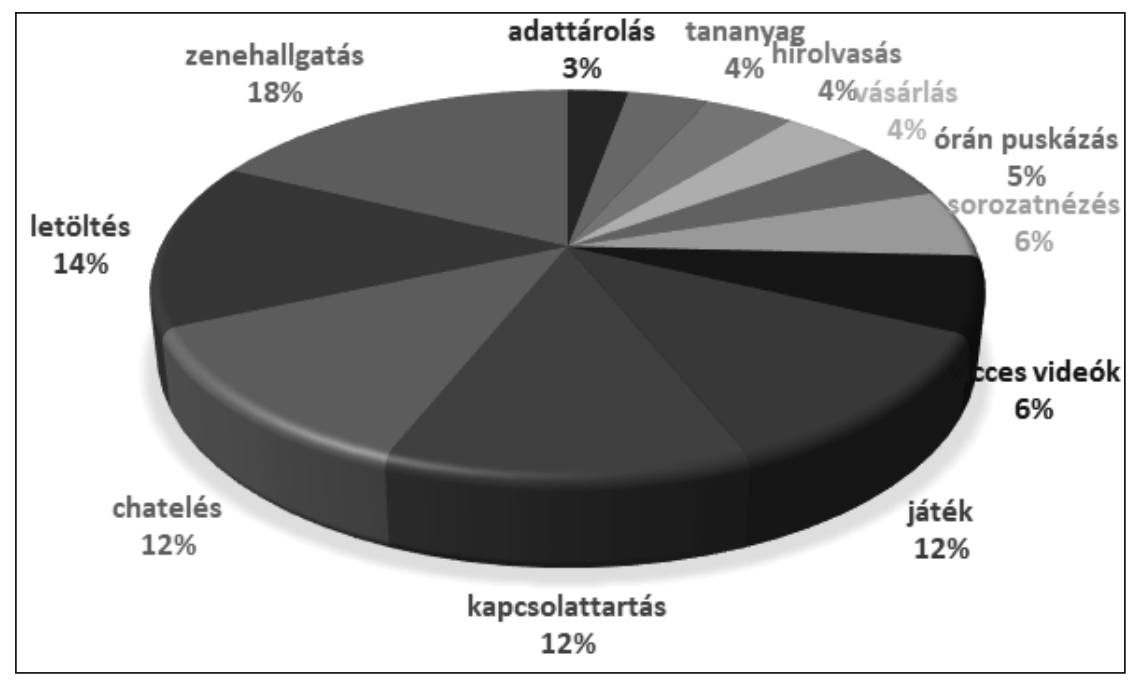

5. ábra

A diákok internetezési szokásai

(Forrás: saját készités a kérdöív eredményei alapján)

Bár az öt legnépszerübb felhasználási módban nem áll olyan elökelö helyen, de a diákok 95\%-a használja az internetet mint forrást tanulmányaihoz, esetleg érdeklődési köréhez kapcsolódó kutatásaiban. Itt szeretném ismét kiemelni a diákok informális ismeretszerzésének fontosságát: számos olyan ismeretet sajátít el a keresés, kutatás közben, amely nem volt a célja, pusztán csak érdekesnek találta, elolvasta az adott cikket, megnézte a Youtube-videót.

Szeretnék utalni az IBM kutatásainak eredményére, mely szerint az élethosszig tartó tanulás során egy alkalmazott milyen forrásokból szerzi a mindennapi munkájához szükséges információkat (Hidvégi, 2003). Arra jutottak, hogy az első alapvető forrás az, amelyet a tanuló a hétköznapi életéből, a családjától kap. 
A kutatás azt is feltárta, hogy a hallgatók a rendelkezésükre álló tudás $80 \%$ át informális úton szerezték, $10 \%$-ot tudatos önképzés folyamán és $10 \%$ volt a hagyományos formális oktatás eredménye. Ha a diákok, mint fentebb már megállapítottam, 3 órát töltenek az internet adta elfoglaltságokkal, akkor körülbelül a szabadidejük 40\%-át ezzel töltik. Van olyan diák, és ez főként az idősebbekre igaz, aki az ébren töltött idejének 37\%-át, szabadidejének $80 \%$-át tölti a kibertérben. Úgy gondolom, megalapozott lehet az a felvetés, hogy ezeknek a gyerekeknek ez jelenti a társas, a családi és a mindennapi élet közegét.

A fent említett időkeretből a megkérdezettek 60\%-a nyilatkozott úgy, hogy fél óránál több, de egy óránál kevesebb időt szán arra, hogy az internet segítségével, tanulmányaival összefüggő tevékenységet végezzen, de három óránál többet senki nem fordít erre a célra (6. ábra).

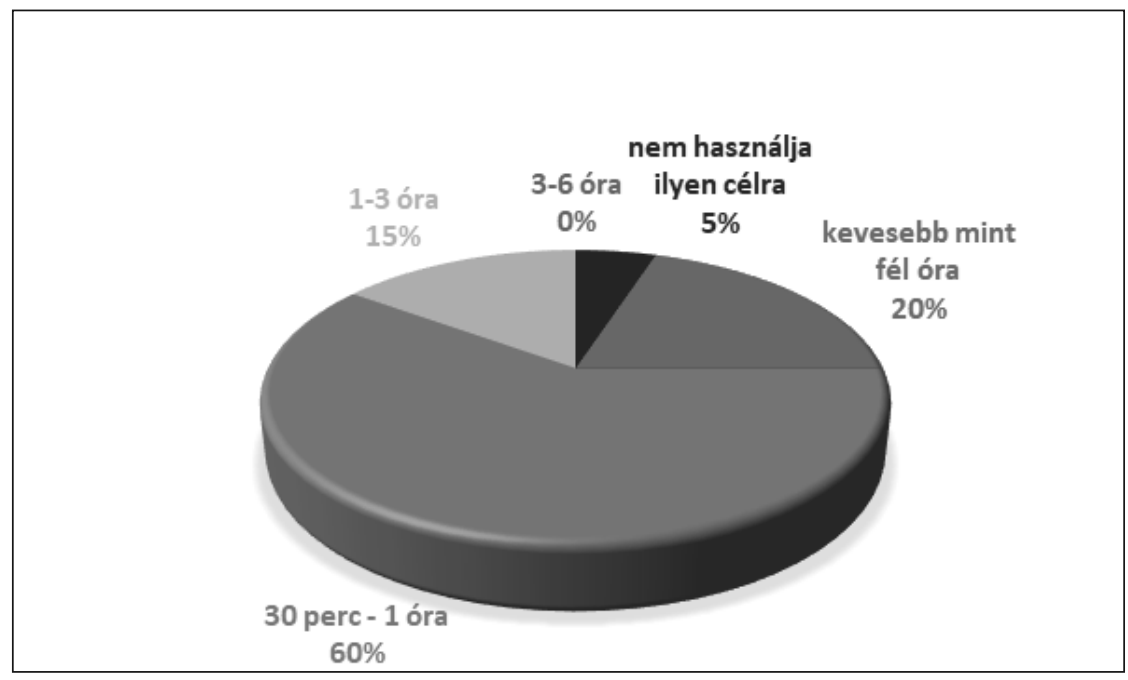

$$
\text { 6. ábra }
$$

A tanulmányokkal összefüggő internethasználat napi átlagos ideje (Forrás: saját készités a kérdöív eredményei alapján)

Ehhez a megállapításhoz hozzátartozik, hogy a válaszolók 95\%-a használja az internetet tanulmányaihoz vagy érdeklődési köréhez. Ezen belül is leginkább beadandó feladatok esetében forrásanyag kereséséhez használják. Amennyiben valamilyen okból kifolyólag a tanóra keretén belül a diák lemaradt, vagy nem tudott megjelenni például betegség miatt, akkor már csak 17\%-uk fordul a világháló adta tudástárhoz, inkább az osztálytárs vagy a tankönyv jegyzetét részesítik előnyben (7. ábra). 


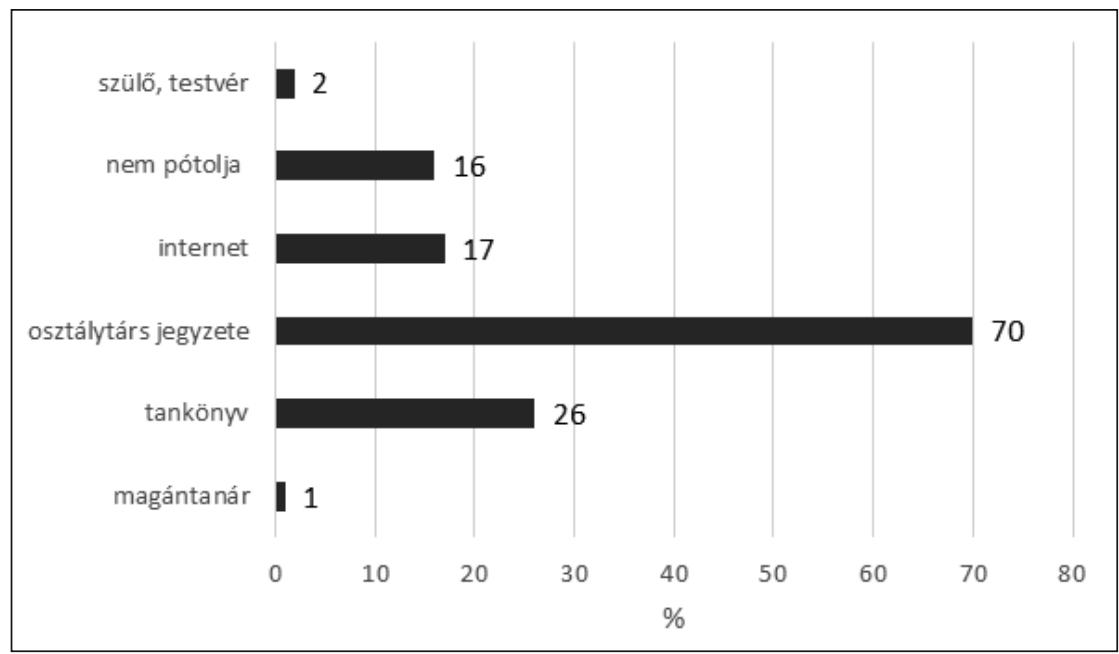

7. ábra

Milyen forrásból zárkóznak fel a diákok?

(Forrás: saját készités a kérdöív eredményei alapján)

Érdekes, hogy beadandó feladatnál pont fordítva történik, ott $88 \%$, aki a világhálót használja forrásként, és emellett 19\% használja a tankönyvet (ezeknél a kérdéseknél nem lett volna reális a válasz, ha csak egy forrást jelölhetnek meg a diákok, hiszen feltételezhetően többet is felhasználnak tanulmányaik, kutatómunkájuk folyamán) (8. ábra).

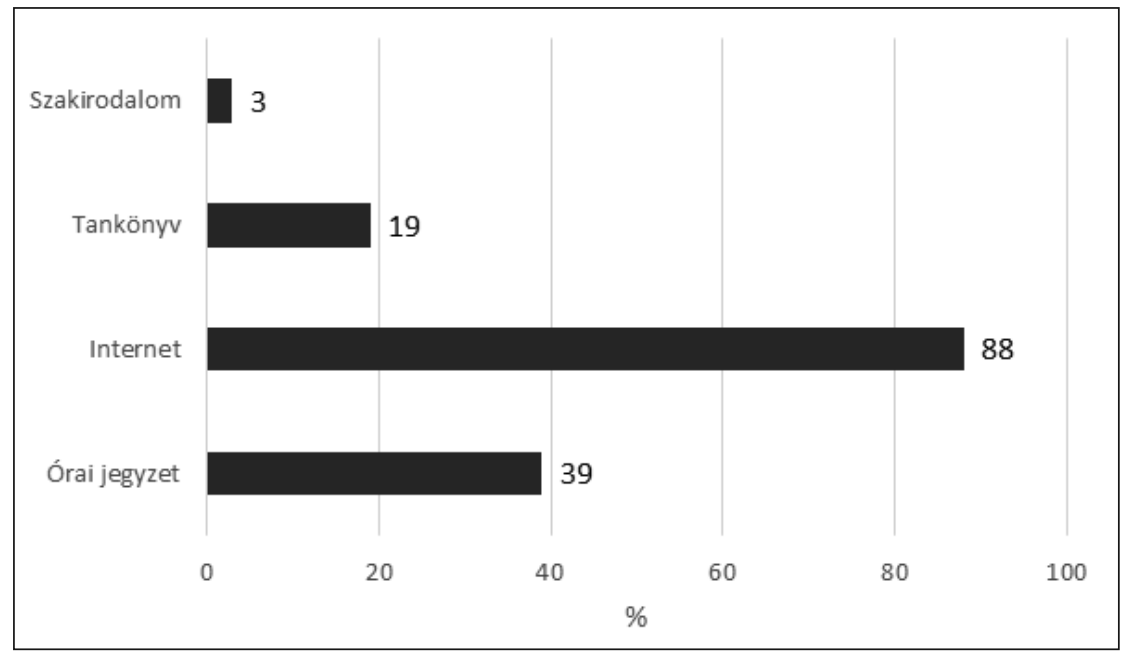

8. ábra

Beadandó feladathoz használt forrás

(Forrás: saját készités a kérdőiv eredményei alapján) 
Ezen rövid bevezetést követően elérkeztünk vizsgálatom fő tárgyához. Az előzőekben már megalapítottam az adott válaszok alapján, hogy a gyerekek sok időt töltenek az internet használatával, és mind tudatosan, mind informális módon tanulnak a világháló segítségével. Arra a kérdésre, hogy a kutatásaik folyamán kiknek, miknek a segítségét veszik igénybe, 83\%-ban jelölték be az internetes keresőt és csak $27 \%$ jelölt meg felnőttet, legyen az tanár vagy szülő. (A válaszadók több választ is megadhattak, így egy válaszlehetőség $100 \%$, ha minden válaszadó megjelölte) (9. ábra).

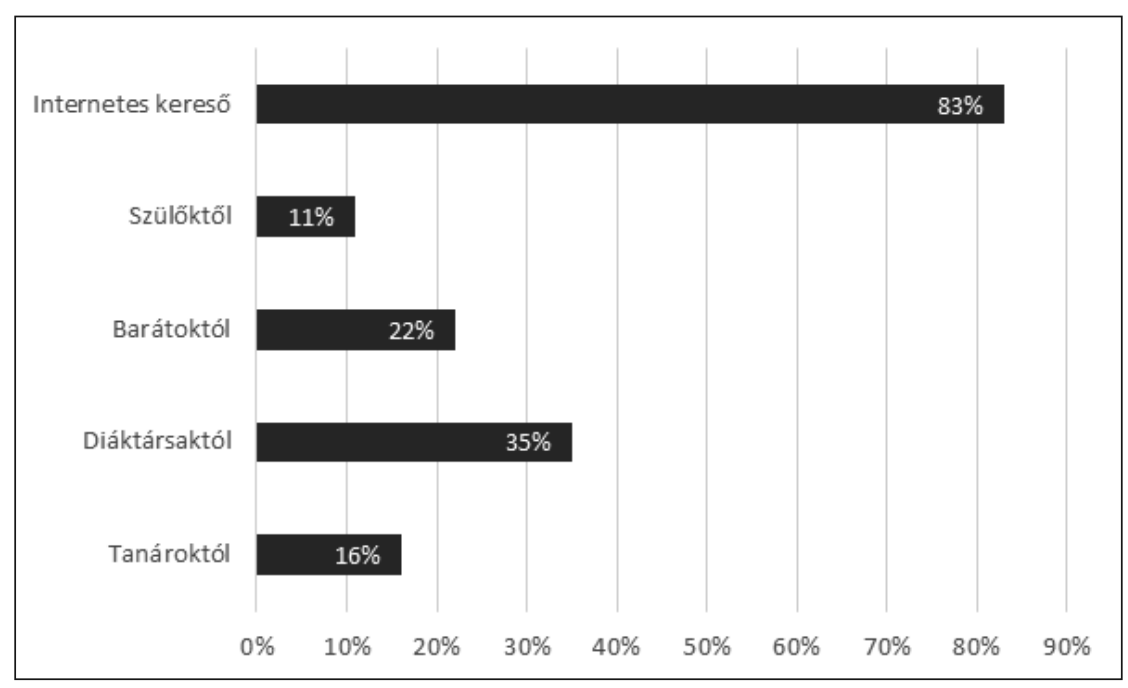

9. ábra

A diákok tájékozódásának forrása tanulmányaik, érdeklödésük terén (Forrás: saját készités a kérdöiv eredményei alapján)

Az adatok elemzése során felvetődött néhány olyan kérdés, amely nem fogalmazódott meg bennem, amikor a kérdöívet készítettem, ezek közé tartozik az is, hogy miért nem kérnek a diákok felnőtt útmutatást. Feltételezéseim lennének, mint például a vizsgált korosztályra jellemző magatartás „én akkor is jobban tudom", lázadnak minden ellen, amit a szülők és általánosságban a felnőttek képviselnek. A másik felvetés a ,just in time" elv meg nem valósulása, azaz a probléma, kérdés felmerülésekor, abban a pillanatban nincs ott sem a tanára, sem az oktatója. Ellenben a keresőmezőbe azonnal be tudja írni, és az azonnal hozni fog számos ,választ”. Így tanáraikhoz inkább már csak akkor fordulnak, ha az internetes keresés nem hozott eredményt, vagy nem hozott számára értelmezhető eredményt, azaz további magyarázatra van szüksége. Mint ahogy a hipotézisben megfogalmaztam, vizsgálatom tárgyát képezte az is, hogy ha már felnőtt útmutatást nem kérnek, akkor legalább ellenőrzik-e a 
forrás hitelességét. Meg kellett állapítanom, hogy a saját magam számára megfogalmazott hipotézisem, miszerint a középiskolás korú diákok egyáltalán nem ellenőrzik az internetes médiában tanulmányaik folyamán szerzett információk valóságtartalmát, hitelességét, nem helytálló. A megkérdezettek 76\%-a arra a kérdésre, hogy szerinte a wikipédiás szócikkeket ellenőrzik-e, hogy mennyire helytállóak, igennel válaszolt. Ebböl a kérdésböl arra a következtetésre jutottam, hogy a gyerekekben felmerül az, hogy amit az interneten látnak, olvasnak, nem feltétlenül igaz, vagy helytálló (10. ábra).

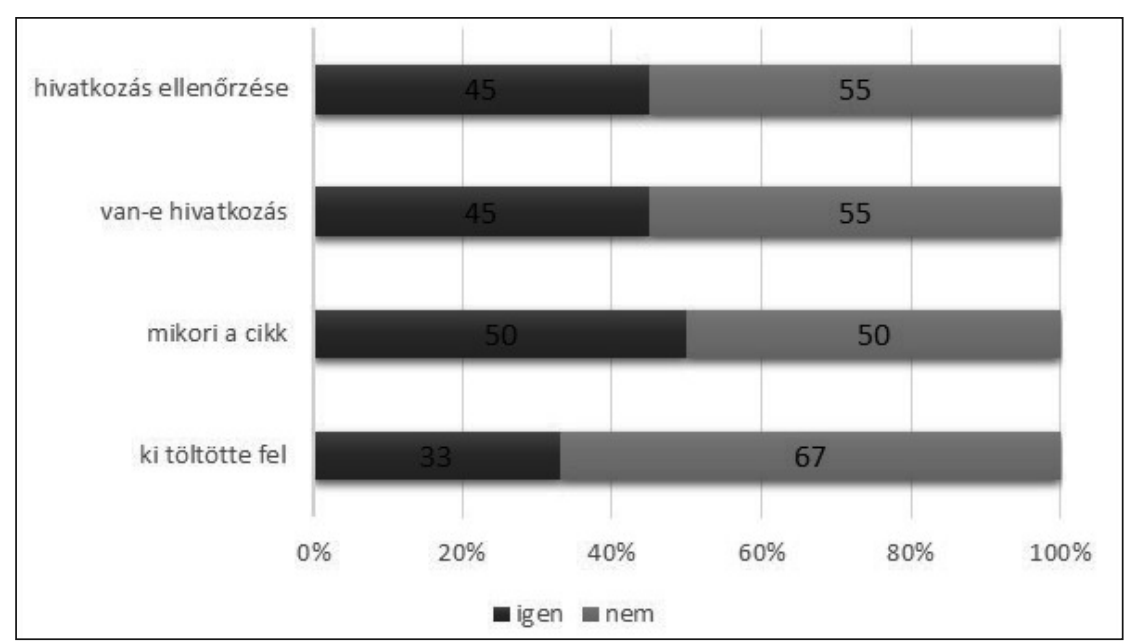

10. ábra

A diákok forrásellenörzési szokásai

(Forrás: saját készités a kérdőiv eredményei alapján)

A további kérdések, amelyek eredménye a fenti ábrán is szemléltetve látható, arra vonatkoztak, hogyha már felmerült bennük a kétely, utánanéznek-e az internetes anyag hitelességének, és ha igen, akkor ezt milyen formában teszik. A válaszolók több mint 40\%-a valamilyen formában ellenőrzi a forrását. A legtöbben az aktualitását ellenőrzik, azaz, hogy a cikk mikor került feltöltésre, a legkevesebben pedig azt figyelik, hogy ki a tartalom feltöltője, a cikk írója. Ezt erősíti meg arra a kérdésre kapott válasz, hogy szerintük mennyi ideig tudta elkerülni a rekordtartó hamis Wikipédia-szócikk ${ }^{1}$, hogy fény derüljön az információ téves, félrevezető voltára, a válaszolók mindössze $20 \%$-a találta el a helyes választ. Ebből arra a következtetésre jutottam, hogy bár élnek a gyanúval, hogy nem mindent lehet készpénznek venni, amit a világhálón találnak, mégis pontosan ennek mértékével még sincsenek tisztában.

\footnotetext{
1 https:/en.wikipedia.org/wiki/Wikipedia:List_of_hoaxes_on_Wikipedia
} 
Eredmények

A dolgozatomban az alábbi kérdéseket tettem fel, amelyekre szerettem volna választ kapni.

- Milyenek a diákok általános internetezési szokásai?

- Tanulnak-e az internet segítségével?

- Tisztában vannak-e azzal, hogy a média és itt föként az internetes média által nyújtott információhalmaz egy része helytelen elemeket tartalmazhat?

- A kapott információkat szürik-e bármilyen módon?

- Mely mechanizmusokat használnak leggyakrabban a diákok az információ szürésére?

\section{A diákok általános internetezési szokásai}

Megállapítható, hogy a diákok jellemzően szórakozás céljából használják az internetet, főleg zenehallgatásra, videók nézésére, játékra, barátaikkal kapcsolattartásra a közösségi weboldalakon. A KSH statisztikájában számottevő helyen szereplő e-mail, adattárolás, on-line újságok, folyóiratok olvasása a 14-18 éves korosztálynál jellemzően nem, vagy alig jelent meg. Megfigyelhető tendencia, hogy a korcsoportokat vizsgálva mind több időt töltenek a diákok a kibertérben, ami számos negatív hatást von maga után, mint például az a tendencia, hogy egyre kevesebb a kézzelfogható barátok száma, és velük is a kapcsolattartás a közösségi oldalakon keresztül történik.

\section{Tanulás az internet segítségével}

A középiskolai korosztály használja az internetet tanulás céljából, de inkább kiegészítő forrásként, leginkább akkor, amikor valamilyen pluszfeladatot kap, vagy valamilyen kiegészítő információra van szüksége. Többnyire a hagyományos tanár általi, vagy az oktatóval közösen készített órai jegyzetre hagyatkozva tanulnak a diákok. 


\section{A diákoknak az internetről származó információk hitelességéről alkotott képe}

A válaszok alapján egyértelmúen tisztában vannak azzal a ténnyel, hogy az interneten található információ valóságtartalma nem feltétlenül helytálló, azonban úgy vélem, mint tudás jelen van, de a gyakorlatban kevesebbet törődnek vele, mint amennyit kellene.

A megkérdezetteknek mindössze fele nyilatkozott úgy, hogy valamilyen formában ellenőrzi a forrása hitelességét, bár már ez is eredmény, hiszen a hipotézis felállításakor még úgy gondoltam, hogy egyáltalán nem ellenőrzik, azért elgondolkodtató, hogy olyan személyek által feltett információkat használnak és tesznek a magukévá, akit nem ismernek, és ezáltal hitelességük is megkérdőjelezhető.

\section{A kapott információk szürése}

A diákok majdnem fele szüri az információkat hitelességük szerint, ami egyben jó, de a pontos értékeket megfigyelve mégis aggódásra adhat okot. Az megnyugtató, hogy legalább van közöttük olyan, aki odafigyel a tartalmakra, azonban ha azt nézzük, hogy a megkérdezettek hány százaléka és leginkább mennyi időt tölt az interneten, akkor a kapott érték arányaiban már nem is tünik annyira biztatónak.

\section{A diákok által az információ szürésére leggyakrabban alkalmazott mecha- nizmusok}

A legtöbbjük a feltöltés dátumát figyeli, ezzel bizonyosodva meg a forrás aktualitásáról, hiszen egy több éves cikk mára már tartalmazhat olyan felvetéseket, adatokat, amelyekről ma már tudjuk, hogy nem állták ki az idő próbáját. Emellett föként a feltöltéshez tartozó hivatkozást nézik meg, hogy van-e egyáltalán, és ha igen, akkor esetenként azt is megnézik hova vezet, és megtekintik az eredeti cikket, feltöltést. Legkevésbé azt figyelik, hogy ki a forrás, aki feltöltötte az adott információt. 


\section{Összegzés}

A tanulás mint folyamat egy tudatos tervezésből, cselekvésből és egy öntudatlan folyamatból tevődik össze. Agyunk nemcsak azt az információt tárolja el, amit mi tudatosan szeretnénk, hanem amit hallunk, látunk, tapasztalunk a környezetünkben. A csúszós úton óvatosabban lépdelünk az első elesés után, és ez rögzül, a következő hóesésnél automatikusan óvatosabban megyünk az utcára. A premodern társadalmakban a gyerekek így tanultak a szüleiktől, környezetüktől. Nincs ez másképp ma sem, mutatja ezt az IBM felmérése is, miszerint a dolgozóik tudásuk 80\%-át informális úton sajátították el, és mindössze $20 \%$ a tudatos tanulás eredménye. Ha ehhez hozzávesszük azt, hogy a megkérdezett diákok minimum $70 \%$-a 3 óránál többet tölt az online térben, azaz a társas közeg, amelyben tapasztalataikat szerzik ez lesz, az informális tanulás során elsajátított ismeretek jelentős része származik tehát innen. A diákok válaszai alapján 95\%-uk használja az internetet tanulmányai során, ami azt jelenti, hogy az online tér a tudatos tanulás terén is megjelenik. Felmerül a kérdés, hogy a mindenki által szerkesztett adathalmazból tanuló diák mennyi helytelen információt sajátíthat el, van-e tudatosság a diákokban. Az álhírek dömpingszerüen lepték el a közösségi médiát és egyéb más forrásokat. Az álhír „téves értesülésből származó vagy megtévesztés céljával terjesztett, valótlannak bizonyuló hír" (Értelemző szótár, 1962, 134. o.).

Ezt figyelembe véve arra a kérdésre kerestem a választ, hogy a diákok maguk ellenőrzik-e azt, amiből akaratlagosan vagy akaratlanul tanulnak. Megállapíthattam, hogy a diákok 50\%-a átlagosan napi 4 óránál többet internetezik. Az online világban töltött idő alatt közösségi médiával, zenehallgatással, videónézéssel foglalkoznak. A diákok föként a tanáraikra, a velük közösen készített jegyzetekre támaszkodnak, és inkább csak akkor keresnek meg valamit az interneten, ha kiegészítő információra van szükségük, tehát nagyban hagyatkoznak az oktatóikra. Az internet akkor kerül elötérbe, de akkor teljes győzelmet arat, amikor a diáknak önálló munkát kell végeznie, ekkor az első helyen szerepel.

A válaszok alapján a diákok tisztában vannak azzal a ténnyel, hogy az internetes médiában szereplö információk valóságtartalma sok esetben megkérdőjelezhető, de a gyakorlatban kevesebbet foglalkoznak ezzel a ténnyel, nem feltétlenül járnak utána minden esetben és próbálnak meggyőződni arról, hogy mi és milyen mértékben helytálló.

A megkérdezettek mindössze fele nyilatkozott úgy, hogy valamilyen formában ellenőrzi a forrás hitelességét. Azonban mielött megörülnénk az 50\%nak, el kell gondolkodnunk azon, hogy a diákok fele egyáltalán nem szüri az információkat, ami az online világban eltöltött idő arányában már nem is tünik 
olyan jónak. A kontrollkérdés arra is rámutatott, hogy az ellenőrzést valószínüleg nem gyakran teszik meg, talán csak akkor, amikor felmerül a gyanú bennük. Összességében gondolatébresztő volt ez a felmérés, rámutatott számos problémára, hogyan lehetne segíteni a diákoknak, hogy önmaguktól merüljön fel bennük a kétely a látottakkal kapcsolatban, valamint hogyan adhatnánk nekik módszereket az információ szürésére.

\title{
Felhasznált irodalom
}

Értelemző szótár (1962): A magyar nyelv értelmező szótára. Akadémiai Kiadó, Budapest.

Hidvégi, P. (2003): A képzés, fejlesztés módszertana, avagy az IBM és az élethosszig tartó tanulás. Új Pedagógiai Szemle, 53. 12. sz. 3-17.

Központi Statisztikai Hivatal (2006): Háztartások információs és kommunikációs technológiai eszközök használata, 2006. Elérhetö: http://www.ksh.hu/ statszemle_archive/2006/2006_05-06/2006_05-06_552.pdf

Központi Statisztikai Hivatal Jelentés (2016): A infokommunikációs technológiák és szolgáltatások helyzete Magyarországon 2015. Elérhető: http:// www.ksh.hu/docs/hun/xftp/idoszaki/ikt/ikt15.pdf (letöltés idöpontja: 2017. április 9.)

\begin{abstract}
Online awareness in the $\mathrm{Z}$ generation

Learning as a process consists of conscious planning and unconscious process. Our brain stores not only the information we want deliberately, but all that we hear, see and experience in our environment. For both adults and children informal learning is part of our lives, but in the case of adults, information is filtered through their experiences children do not have such filters in their existing knowledge network. Considering that students spend more and more time in the online space and due to this fact it becomes the social medium from which students learn in an informal way, the question arises as to what content the child encounters where information is almost infinite, but anyone can edit it. According to the previously mentioned phenomenon, it is an important question whether children are able to handle the stimuli they receive.
\end{abstract}

